\title{
EVALUATION OF HEALTH BENEFITS OF PERIPHERAL RESISTANCE TRAINING BASED ON ENERGY EXPENDITURE IN WOMEN AGED 25-35 YEARS
}

\section{OCENA PROZDROWOTNYCH KORZYŚCI Z OBWODOWEGO TRENINGU OPOROWEGO NA PODSTAWIE WYSIŁKOWEGO WYDATKU ENERGETYCZNEGO U KOBIET W WIEKU 25-35 LAT}

\author{
Michał Rozpara $^{1(\mathrm{~A}, \mathrm{~B}, \mathrm{C}, \mathrm{D}, \mathrm{E})}$, Ewa Nowak $^{2(\mathrm{~A}, \mathrm{~B}, \mathrm{E}, \mathrm{F})}$, Agnieszka Nawrocka ${ }^{1(\mathrm{~A}, \mathrm{~B}, \mathrm{D}, \mathrm{E})}$, \\ Jacek Polechoński ${ }^{1(\mathrm{~B}, \mathrm{D}, \mathrm{F})}$, Małgorzata Dębska $^{1(\mathrm{~B}, \mathrm{E}, \mathrm{F})}$, Władysław Mynarski $^{1(\mathrm{~A}, \mathrm{D}, \mathrm{E}, \mathrm{F})}$
}

${ }^{1}$ Faculty of Physical Education, Institute of Tourism and Pro-Health Physical Activity, The Jerzy Kukuczka Academy of Physical Education in Katowice, Poland

${ }^{2} \mathrm{PhD}$ Studies, The Jerzy Kukuczka Academy of Physical Education in Katowice, Poland

Authors' contribution Wkład autorów: A. Study design/planning zaplanowanie badań B. Data collection/entry zebranie danych C. Data analysis/statistics dane - analiza i statystyki D. Data interpretation interpretacja danych E. Preparation of manuscript przygotowanie artykułu F. Literature analysis/search wyszukiwanie i analiza literatury G. Funds collection zebranie funduszy
Tables: 3

Figures: 0

References: 40

Submitted: 2017 Nov 14

Accepted: 2018 Jan 30

\section{Summary}

Background. The aim of this study was to evaluate the potential health benefits of peripheral strength training in women according to the ACSM protocol.

Material and methods. This study involved 90 women aged $29.2 \pm 3.3$ years, who performed three sets of 10 resistance exercises repeated 10-15 times with a $60 \%$ load of 1 RM. Energy expenditure (EE) during the exercises was measured with the Caltrac Monitor accelerometer. Their intensity (relative EE) was expressed in $\mathrm{kcal} / \mathrm{min}$. Results were compared to the recommended volume of daily physical activity according to the proposals of Paffenbarter and colleagues. Effort of at least moderate intensity (5.5-7.4 kcal/min) was considered to be beneficial for health.

Results. The average EE of the entire training was $293 \mathrm{kcal}$, resistance exercises $230 \mathrm{kcal}$ and the average intensity effort was $7.3 \mathrm{kcal} / \mathrm{min}$. It was shown that peripheral resistance training, according to the ACSM Protocol, allowed all examined women to fulfil pro-health recommendations for the volume and intensity of daily physical activity (in terms of absolute and relative energy expenditure).

Conclusions. Peripheral resistance training in accordance with ACSM protocol can be recommended to women aged 25-35 as a form of implementation of pro-health recommendations in the scope of due daily energy expenditure on physical effort, as well as its intensity.

Keywords: physical activity, recommendations, energy expenditure, resistance training, women

\section{Streszczenie}

Wprowadzenie. Celem badań była ocena potencjalnych korzyści zdrowotnych obwodowego treningu siłowego prowadzonego wg protokołu ACSM u kobiet.

Materiał i metody. Badano 90 kobiet w wieku 29.2 \pm 3.3 lat, które wykonywały trzykrotnie 10 ćwiczeń oporowych powtarzanych $10-15$ razy z obciążeniem $60 \% 1 \mathrm{RM}$. Wydatek energetyczny (EE) podczas ćwiczeń mierzono akcelerometrem Caltrac Monitor. Ich intensywność (względny EE) ujęto $\mathrm{w} \mathrm{kcal} / \mathrm{min}$. Uzyskane wyniki porównano do zalecanej dla zdrowia objętości dziennej aktywności fizycznej wg propozycji Paffenbargera i współautorów. Za prozdrowotny uznano wysiłek o co najmniej umiarkowanej intensywności (5.5-7.4 kcal/min).

Wyniki. Średni EE całego treningu wyniósł 293 kcal, ćwiczeń oporowych $230 \mathrm{kcal}$, średnia intensywność wysiłku kształtowała się na poziomie $7.3 \mathrm{kcal} / \mathrm{min}$. Wykazano, iż obwodowy trening oporowy wg Protokołu ACSM pozwolił wszystkim badanym kobietom na wypełnienie prozdrowotnych zaleceń dla objętości i intensywności dziennego wysiłku fizycznego (w zakresie bezwzględnego i względnego wydatku energetycznego).

Wnioski. Obwodowy trening oporowy wg protokołu ACSM można polecać kobietom w wieku 25-35 lat jako formę realizacji prozdrowotnych rekomendacji w zakresie należnego dziennego wydatku energetycznego na wysiłek fizyczny, jak i jego intensywności.

Słowa kluczowe: aktywność fizyczna, zalecenia, wydatek energetyczny, trening oporowy, kobiety 


\section{Introduction}

It is increasingly considered that undertaking physical activity for health purposes is an expression of personal culture and civilisation progress in the awareness of societies with regard to the importance of maintaining one's own health. The current state of knowledge allows us to treat physical activity as an independent positive factor and a measure of health, as well as a basic health behaviour [1,2]. Meanwhile, the results of national studies, aimed at assessing physical activity in the Polish society in the context of achieving health benefits, indicate that this level is unsatisfactory $[3,4,5,6]$.

In recent decades there has been a steady progress in the identification of the complex of physical activity parameters in the guidelines for health promotion in people of different ages, as well as a tendency to tighten the minimum criteria for their level $[7,8,9,10,11]$. As a result, there has been a growing interest in searching for and improving the tools for measuring (estimating) different parameters of physical activity, enabling the assessment of its potential and pro-health benefits of the exercising (training) person.

An important indicator of the level of physical activity (PA) is energy expenditure (EE) and caloric cost (CC), considered to be the basic criterion for assessing its heath beneficial character [7, 12, 13]. The monitoring of energy expenditure, while undertaking various physical activities in everyday life or during health training, is a largely ignored issue [14], which especially (in particular) concerns the measurement (estimation) of energy of the strength (resistance) exercises $[15,16]$. In the past, the energy cost (EC) of such an effort was estimated, among others, indirectly through the analysis of gas exchange (indirect calorimetry) during strength exercises and in the post-workout restitution phase $[17,18]$. In experimental studies, the indirect calorimetry method is generally used to evaluate energy expenditure during resistance training (RT) of women and men [19, 20, 21]. It is necessary in this case to possess expensive measuring equipment, however, its use in research of a large group of people practising, for example, resistance training is not possible, therefore the commonly available technique of accelerometery is also used [22].

The necessity to explore reliable tools for evaluation of energy expenditure during resistance exercises results from the current recommendations for pro-health PA. The imperative to perform them not less than twice a week, with at least moderate intensity, is taken into account $[10,11]$. The volume and intensity indicators of resistance exercises can be absolute energy expenditure (AEE) expressed in kilocalories (kcal) and relative energy expenditure (REE) expressed in kilocalories per minute (kcal/min) or as a conventional METs unit (kcal/ $\mathrm{kg} / \mathrm{h})[23,9,24]$.

Performing resistance exercises of the recommended characteristics is to be used in adults, mainly for the prevention of diseases of the motor and nervous systems, such as: chronic back, joints and muscles pain, osteoporosis, sarcopenia, Parkinson's disease, which are included in the group of civilization and hypokinetic diseases (due to the lack of physical activity). Not without significance is also the improvement of functional fitness that facilitates everyday life activities and general physical condition necessary for a satisfactory quality of individual life $[8,25,26,27]$.

The aim of this study is to evaluate the health benefits of resistance exercises carried out in the form of a circuit resistance training in accordance with the ACSM protocol (ACSM Resistance Training Protocol) [10] based on the monitoring of energy expenditure during exercise with the Caltrac Monitor accelerometer in women aged 25-35 years.

\section{Material and methods}

The study was conducted at the turn of April and May 2015 among 90 women aged 29.2 \pm 3.3 years attending regular (three times a week) strength training in the fitness centre "Aqua Planet" in Trzebinia, Małopolskie Voivodeship (Poland). Recruitment for the study was conducted in the form of voluntary applications (arbitrary selection) from among women with 2-3 years of training experience. The participants were acquainted with the aim and programme (scope) and the planned scope of the research a few days before the start of the training. It was also pointed out that it is possible to resign at any time during the research without stating the reasons. Descriptive characteristics of basic features and indicators of somatic structure of the studied women are presented in Table 1. 
Table 1. Descriptive statistics of biometric parameters of the studied women $(n=90)$

\begin{tabular}{|c|c|c|c|c|c|}
\hline Parameters & Unit of measure & $\overline{\mathbf{x}}$ & SD & Min & Max \\
\hline $\mathrm{BH}$ & $\mathrm{cm}$ & 165.0 & 4.8 & 159.0 & 185.0 \\
\hline $\mathrm{BM}$ & $\mathrm{kg}$ & 60.5 & 5.0 & 51.0 & 70.0 \\
\hline $\mathrm{BMI}$ & $\mathrm{kg} / \mathrm{m}^{2}$ & 22.2 & 1.2 & 19.9 & 24.8 \\
\hline $\mathrm{BF}$ & $\%$ & 22.5 & 4.8 & 11.0 & 33.0 \\
\hline $\mathrm{VFI}$ & unit & 2.4 & 1.5 & 1.0 & 7.0 \\
\hline
\end{tabular}

Note:

$\mathrm{BH}$ - body height, BM - body mass, BMI - body mass index, FR - fat rage, VFI - visceral fat indicator.

The following measurements were included in the programme:

- body height with the use of medical weight Radwag model 100/200 OW,

- body composition with the use of Tanita MC780S bioimpedance analyser,

- the caloric cost of strength training in the form of circuit resistance training - CRT with a single-axis Caltrac Monitor accelerometer from Muscle Dynamitcs. Inc. Torrance. CA, USA.

In the first stage of the study, carried out in the morning on an empty stomach, after at least eight hours of sleep and 12 breaks from increased physical activity, the body height (BH), body mass (BM), relative body mass indexes (BMI), degree of body fatness (BF) and visceral (cellular) fat indictor (VFI) were measured with the women wearing a shirt and training shorts.

In the afternoon hours of the second stage, physical effort during circuit resistance training was monitored with the Caltrac Monitor accelerometer. The data on gender, age, height and weight were entered into the device's memory and carried in a special case attached to a belt placed at the height of the waist. The accelerometer provided the data on absolute (kcal) and relative (kcal/min) energy expenditure of this type of classes separately for the warm-up (EE WUP), the first (EE I), the second (EE II) and the third (EE III) circuit training. After each reading of the caloric cost, the device was reset.

During the warm-up (endurance effort) the Caltrac Monitor was set to the basic mode, whereas when performing resistance exercises (strength effort) to the strength training mode. All monitored trainings, carried out in accordance with ACSM recommendations [10], consisted of a warm-up (introductory part), exercises for the main muscle parts (main part), stretching and calming exercises (final part). The cross-country warm-up for all subjects was carried out on a moving treadmill at a speed of $7 \mathrm{~km} / \mathrm{h}$ over a period of 10 minutes.

After the warm-up, the subjects performed three sets of 10 exercises (1-8 with an external load of 9-10 with own body weight). The training circuit consisted of the following exercises according to the order in which they were performed: 1 . Barbell squats, 2. Barbell bench press, 3. Deadlift, 4. Wide-grip lat pulldown, 5. Dumbbell shoulder press, 6. Standing dumbbell calf raise, 7. Close-grip EZ bar curl, 8. EZ bar skullcrusher, 9. Sit-ups, 10 Push-ups.

Exercises 1-8 and 10 were performed 10 times, the ninth was repeated fifteen times. A single exercise with the acceptance of the starting position lasted about 60 seconds, the transition to the next position (a form of active rest break between exercises) lasted 30 seconds. The total time of performing a single set of exercises was 15 minutes, while a set of three was 45 minutes.

Throughout one day, 3-5 persons, for whom individual loads were prepared at successive workstations of the training circuit, were examined individually. The amount of external load (training weight) was set in exercises 1-8 at $60 \%$ of $1 \mathrm{RM}$ of the examined person. The size of 1RM for particular exercises was estimated for each of the women on the basis of Brzycki's formula [28] $1 \mathrm{RM}=\mathrm{W} \times 36 /(37-\mathrm{R})$, where: $\mathrm{W}$ - the external load with which one has been trained so far in a specific exercise (result of an interview with the respondents), $\mathrm{R}$ - the maximum number of repetitions with $\mathrm{W}$ (result of $\mathrm{R}$ tests for a specific exercise).

Obtained data on absolute and relative caloric cost (volume and intensity) of peripheral training was used to assess its pro-health value (health benefiting character). Physical effort of about $300 \mathrm{kcal}$ per day is considered beneficial for health in 20-59 years old and a body weight of $70 \mathrm{~kg}$ [7]. Based on this assumption, the daily volume of health benefiting exercise was estimated for each of the women according to the formula: RAEE [kcal/day] $=300[\mathrm{kcal} / \mathrm{day}] \times \mathrm{BM}[\mathrm{kg}] / 70$ [kg], where: RAEE - due daily caloric cost (recommended daily volume) of physical activity, BM - body weight of the person for whom RAEE was determined. In the case of exercise intensity, physical effort of at least moderate intensity, i.e. between $5.5-7.4 \mathrm{kcal} / \mathrm{min}[10,11,23]$, was considered to be health benefiting.

Arithmetic averages ( $\bar{x}$ ), standard deviations (SD) and minimum (Min) and maximum (Max) values for the variables under consideration were used in the statistical elaboration of the collected empirical material. All analyses were carried out with the use of Statistica 12.0 computer application by StatSoft. 


\section{Results}

The average absolute energy expenditure (volume of exercise) during the circuit resistance training in the group of 25-35 years old women was 292.9 $\pm 8.1 \mathrm{kcal}$ (10-minute initial part of EE WUP 62 kcal, 45-minute main part of EE I-III 230 kcal). The average relative energy expenditure (effort intensity) was $7.3 \pm 0.2 \mathrm{kcal} / \mathrm{min}$ and was $1.5 \mathrm{kcal} / \mathrm{min}$ higher in the main part of the training compared to the warm-up (Table 2).

Table 2. Volume (kcal) and intensity (kcal/min) of physical activity during CRT in a group of women $(\mathrm{n}=90)$

\begin{tabular}{|c|c|c|c|c|c|}
\hline \multirow{2}{*}{ Parameters } & Unit of measure & $\overline{\mathbf{x}}$ & $\mathbf{S D}$ & Min & Max \\
\hline \multirow{2}{*}{ EE VEO } & $\mathrm{kcal}$ & 61.7 & 5.1 & 52.0 & 71.4 \\
\cline { 2 - 6 } & $\mathrm{kcal} / \mathrm{min}$ & 6.2 & 0.5 & 5.2 & 7.1 \\
\hline \multirow{2}{*}{ EE I } & $\mathrm{kcal}$ & 77.5 & 3.8 & 70.0 & 86.0 \\
\cline { 2 - 6 } & $\mathrm{kcal} / \mathrm{min}$ & 7.7 & 0.4 & 7.0 & 8.6 \\
\hline \multirow{2}{*}{ EE II } & $\mathrm{kcal}$ & 76.4 & 3.1 & 70.0 & 85.0 \\
\cline { 2 - 7 } & $\mathrm{kcal} / \mathrm{min}$ & 7.6 & 0.3 & 7.0 & 8.5 \\
\hline \multirow{2}{*}{ EE III } & $\mathrm{kcal}$ & 77.3 & 3.0 & 7.0 & 8.0 \\
\cline { 2 - 7 } & $\mathrm{kcal} / \mathrm{min}$ & 7.7 & 0.3 & 273.1 & 312.3 \\
\hline \multirow{2}{*}{$\mathrm{EE}$} & $\mathrm{kcal}$ & 292.9 & 8.1 & 6.8 & 7.8 \\
\hline
\end{tabular}

Note:

EE WP - caloric cost of the warm-up, EE I - caloric cost of the first circuit, EE II - caloric cost of the second circuit, EE III caloric cost of the third circuit, EE - caloric cost of the circuit training.

In the observed group of women, the absolute caloric cost of hourly peripheral training according to ACSM guidelines was on average $44.7 \pm 18.0 \mathrm{kcal}(10-27 \%)$ higher than recommended for health benefits, while the relative cost was $1.8 \pm 0.2 \mathrm{kcal} / \mathrm{min}$ (29-37\%). The minimum and maximum values of variables characterizing the implementation of pro-health recommendations in terms of volume (EE-RAEE) and intensity (EE-RAEE) of physical activity indicate that all women met (fulfilled) them in over 100 percent during circuit resistance training carried out according to ACSM guidelines (Table 3).

Table 3. Degree of implementation of pro-health volume (kcal, \%) and intensity (kcal/min, \%) of physical activity during CRT in the group of women $(n=90)$

\begin{tabular}{|c|c|c|c|c|c|}
\hline \multirow{2}{*}{ Parameters } & Unit of measure & $\overline{\mathbf{x}}$ & SD & Min & Max \\
\hline \multirow{2}{*}{ EE-RAEE } & $\mathrm{kcal}$ & 44.7 & 18.0 & 8.4 & 78.1 \\
\cline { 2 - 6 } & $\%$ & 118.6 & 8.6 & 102.9 & 136.7 \\
\hline \multirow{2}{*}{ EE-RREE } & $\mathrm{kcal} / \mathrm{min}$ & 1.8 & 0.2 & 1.3 & 2.3 \\
\cline { 2 - 6 } & $\%$ & 133.1 & 3.7 & 124.1 & 142.0 \\
\hline
\end{tabular}

Note:

EE-RAEE - volume of exercise during peripheral training compared to that recommended for obtaining health benefits (RAEE $=248 \pm 20 \mathrm{kcal}, 210-290 \mathrm{kcal}$ ).

EE-RREE - exercise intensity during peripheral training compared to that recommended for obtaining health benefits, i.e. medium (moderate) intensity (RREE=5.5-7.4 kcal $/ \mathrm{min})$.

\section{Discussion}

In the course of this study it was assessed to what extent the resistance training of women, conducted as a circuit resistance training according to ACSM (single-set resistance training protocol), meets the requirements (recommendations) for physical activity for pro-health PA in terms of volume and intensity (absolute and relative energy expenditure). Women aged 25-35 years with at least 2 years of personal experience of participation in regular strength trainings were examined. Most of the subjects had a normal body structure (BMI=19.9$24.8 \mathrm{~kg} / \mathrm{m}^{2}$ ), however, there were individual cases of women with elevated body fat content (BF>32\%) [29]. At the same time, the average level of visceral adipose tissue (VFI=1.0-7.0 unit) allows to treat patients with low risk of cardiovascular diseases (arterial hypertension, ischemic heart disease) or metabolic diseases (insulin resistance, type II diabetes). 
After the warm-up, the examined patients were able to perform the three-set of resistance training without interruption consisting of 10 strength exercises over a period of three years. The selection of exercises, the size of external load, the number of repetitions of a single exercise and the number of repetitions of an exercise circuit was based on strictly defined recommendations of ACSM experts for health benefiting CRT $[9,10]$.

The Caltrac Monitor accelerometer was used in the assessment of energy expenditure during the exercises, as it is one of the few devices of this type that allows for different modes of recording accelerations in endurance (aerobic) and resistance (anaerobic) exercises. It allowed to estimate both the energy expenditure during warmup on the moving treadmill in the so-called basic mode and during resistance exercises in the force training mode. In order to increase the reliability of the observations of energy expenditure during the power training, the research was conducted individually in optimal external circumstances (in the presence of members of the research team only).

In previous studies, the energy expenditure during aerobic efforts was assessed more frequently, mainly on the basis of the amount of oxygen absorbed or achieved during exercise pulse [30], while resistance training (weight training) was the subject of less frequent studies [18, 32].

The results of our own research indicate a high similarity of the average energy expenditure during exercise on three consecutive circuits and their relatively low differentiation in the studied group of women. This may indicate a high state of strength fitness (strength conditions), resulting from training experience. On the other hand, the unified nature and duration of exercises was most probably the reason for a significant similarity of the mean ( $\bar{x}$ ) results and their slight dispersion (SD) in the assessment of the volume and intensity of physical activity in subsequent exercise circuits. It probably also indicates the usefulness of the research tool (Caltrac Monitor) in monitoring energy expenditure during circuit resistance training, which requires empirical confirmation in further studies. The hypothesis seems to confirm the fact that the collected empirical material was to a large extent similar to the results of previous studies in which energy expenditure during strength training was assessed. For example, in the Phillips \& Ziuraitis [32] study, conducted among 12 women and men with the technique of indirect calorimetry, the energy expenditure during one exercise circuit reached an average level of about $81 \mathrm{kcal}$ in women. In a pioneering study conducted by Wilmore et al. [23] women aged 17-26 years consumed more than $360 \mathrm{kcal}$ during one hour's circuit weight training, which is comparable to their own study of about $90 \mathrm{kcal}$ in 15 minutes (single set circuit training). It is worth mentioning, however, that these women were younger and practising sports. Almost identical to their own were also the results of the EE assessment with the Caltrac Monitor accelerometer during the recreational practice of selected combat sports by young men who were beginners in these forms of physical activity. During an hour-long strength and speed training effort, they spent $270 \mathrm{kcal} /$ hour, i.e. $67 \mathrm{kcal}$ per quarter of an hour [15].

The average intensity of effort during the whole 60 -minute CRT reached the level of $7.3 \mathrm{kcal} / \mathrm{min}(7.2 \pm 0.5$ METs) in subsequent training circuits, respectively: 7.7, 7.6, $7.7 \mathrm{kcal} / \mathrm{min}$ (7.6, 7.5, 7.8 METs). Therefore, it was an effort at the borderline of moderate and high intensity [11]. In a study by Wilmore et al. [23] and Reilly [33], the intensity of women's effort during circuit weight training ranged from slightly lower 6.6-6.7 kcal/min. For comparison, the intensity of exercises (relative EE) from the MMA area in novice participants was determined at the level of $6.0 \pm 2.1 \mathrm{kcal} / \mathrm{min}(6 \mathrm{METs})[34,35]$. In compendia of intensity of various forms of physical activity, peripheral training was classified as conditionings exercise with moderate (4.3 METs) or high effort (8.0 METs) [24]. In the latter case, the breaks between exercises should be with minimal rest, whereas the resistance to overcome should be high. i.e. exercise with kettlebells. This was the nature of the exercises in our own research, hence their intensity was close to the lower limit of the high level.

The research has shown that during the observed strength training in the form of circuit resistance training, all women significantly exceeded the daily energy expenditure on physical activity recommended for health by Paffenbarter and others [7] (on average by more than 40\%). Its implementation would ensure that the majority of the examined patients have already completed two-set resistance training of the ACSM protocol.

In previous studies, the most frequently evaluated were the compliance with pro-health recommendations based on aerobic (endurance) and mixed effort exercises [36, 37, 15, 38, 39, 40]. For instance, Scheers and others [38] demonstrated that the WHO recommended weekly volume of physical activity of moderate intensity (150 min. MPA) was implemented by more than $68 \%$ of women. In the case of high-intensity efforts (75 min. VPA), only less than $16 \%$ of this group met this criterion.

In the aforementioned studies by Mynarski and co-authors [15], approximately $80 \%$ of young men practising recreational combat sports met the criteria for pro-health intensity of effort. In this context, it should be added here that the parameters of recommended health benefits (PA) are the same for women and men.

Few similar studies have been carried out on the fulfilment of pro-health recommendations regarding the intensity of strength training, which should be undertaken at least twice a week with at least moderate intensity. 
Most of these observations were based on a small number of research samples, as compared to the ones described in this study (90 women) [25, 26, 27]. The criterion of intensity of effort was met by all participants of own research already during the single-set resistance training.

To conclude, it is important to emphasise that the studied women met both evaluated criteria of prohealth physical activity, which should be considered a fundamental value of strength training. The results of the research conducted so far indicate that the percentage of respondents meeting specific recommendations decreases with the number of criteria included in them $[36,35,38,40]$.

\section{Conclusions}

1. During peripheral resistance training according to ACSM protocol, the examined women significantly exceeded the recommended daily energy expenditure.

2. Strength (resistance) exercises performed during resistance training were at least of moderate intensity in all subjects.

3. Peripheral strength training can be recommended to women aged 25-35 as a form of implementing prohealth recommendations for daily energy expenditure and recommended intensity of effort.

\section{Disclosures and acknowledgements}

The results presented in the report are part of the research carried out within the framework of the research project entitled "Diagnosis and evaluation of physical activity and morphological parameters of adults and the elderly in relation to pro-health recommendations". The consent to its implementation was granted by the Bioethics Committee for Scientific Research at the Jerzy Kukuczka Academy of Physical Education in Katowice (Resolution No. 2/2012 of 13 December 2012).

\section{References:}

1. Fogelholm M. Physical activity, fitness and fatness: relations to morality, morbidity and disease risk factors. A systematic review. Obes Rev. 2010; 11(3): 202-221. https://doi.org/10.1111/j.1467-789X.2009.00653.x

2. Kaar JL, Luberto CM, Campbell K, Huffman JC. Sleep, health behaviors and behavioral interventions: reducing the risk of cardiovascular disease in adults. World J Cardiol. 2017; 26(5): 396-401. https://doi.org/10.4330/wjc.v9.i5.396

3. Bergier J. The level of physical activity in society today - the problem of modern civilization (research overview). Human and Health. 2012; 6 (1): 13-22.

4. Bergier J, Kapka-Skrzypczak L, Biliński P, Paprzycki P, Wojtyła A. Physical activity of Polish adolescents and young adults according to IPAQ: a population based study. Ann Agric Environ Med. 2012; 19(1): 109-115.

5. Biernat E, Piątkowska M. [Recreational physical activity of Poles compared to other Europeans. Report for Department of Analyses and Sports Policy of Ministry of Sport and Tourism]. Warszawa: Ministerstwo Sportu i Turystyki; 2012 (in Polish).

6. Mynarski W, Nawrocka A, Rozpara M, Garbaciak W. Physical activity of male and female adolescents living in a town and a city in the context of public health recommendations. Biomed Hum Kin. 2012; 4: 18-23. https://doi.org/10.2478/v10101-012-0004-2

7. Paffenbarger RS, Hyde RT, Wing A. Physical activity and physical fitness as determinants of health and longevity. In: Bouchard R, Shephard T, Stephens J, Sutton J, McPherson BD., editors. Exercise, fitness, and health: a consensus of current knowledge: proceedings of the International Conference on Exercise, Fitness and Health; 1988 May 29 - Jun 3; Toronto. Champaign IL: Human Kinetics Publishers; 1990. p. 33-48.

8. Haskell W, Lee I, Paite R, Powell K, Blair S, Franklin B, et al. Physical activity and public health. Updated recommendation for adults from the American College of Sports Medicine and the American Heart Association. Med Sci Sports Exerc. 2007; 8(39): 1423-1434. https://doi.org/10.1249/mss.0b013e3180616b27

9. Rahl R. Physical activity and health guidelines: recommendations for various ages fitness levels, and conditions from 57 authoritative sources. Champaign: Human Kinetics Publisher; 2010.

10. American College of Sport Medicine. General principles of exercise prescription. ACSM's guidelines for exercise testing and prescription. Eighth edition. Baltimore: Lippincott, Williams and Wilkins; 2010.

11. WHO. Global recommendations on physical activity for health 2010 [Internet]. Geneva: WHO; 2010 [cited 2014 Sep 20]. Available from: http:/whqlibdoc.who.int/publications/2010/9789241599979eng.Pdf

12. Caspersen CJ, Powell KE, Christenson GM. Physical activity and physical fitness: definitions and distinctions for health-related research. Public Health Rep. 1985; 1: 126-131. 
13. Strath SJ, Kaminsky LA, Ainsworth BE, Ekelund U, Freedson PS, Gary RA, et al. Guide to the assessment of physical activity: clinical and research applications. Circulation. 2013; 128: 2259-2279. https://doi.org/10.1161/01.cir.0000435708.67487.da

14. Haltom RW, Kraemer RR, Sloan RA, Hebert EP, Frank K, Tryniecki JL. Circuit weight training and its effects on excess postexercise oxygen consumption. Med Sci Sports Exerc. 1999; 31: $1613-1618$. https://doi.org/10.1097/00005768-199911000-00018

15. Mynarski W, Grabara M, Rozpara M, Nawrocka A, Powerska-Didkowska A, Borek Z. Energy expenditure of nordic walking and conventional walking assessed by accelerometer. Biomed Hum Kin. 2014; 6(1): $109-115$. https://doi.org/10.2478/bhk-2014-0018

16. Mynarski W, Królikowska B, Rozpara M, Nawrocka A, Puciato D. The caloric cost of combat sports and martial arts training in relation to health recommendations - initial research. Arch Budo. 2013; 2: 127-133.

17. Biernat E, Boguszewski D. The level of physical activity of the working inhabitants of Warsaw practising martial arts and combat sports. Arch Budo. 2015; 11: 69-77.

18. Haddock B, Wilkin L. Resistance training volume and post exercise energy expenditure. Int. J Sports Med. 2006; 27(2): 143-148. https://doi.org/10.1055/s-2005-865601

19. Phillips SM, Winett RA. Uncomplicated resistance training and health-related outcomes: evidence for a public health mandate. CSMR. 2010; 9(4): 208-213. https://doi.org/10.1249/JSR.0b013e3181e7da73

20. Heden T, Lox C, Rose P, Reid S, Erik P. One-set resistance training elevates energy expenditure for $72 \mathrm{~h}$ similar to three set. Eur J Appl Physiol. 2011; 111(3): 477-484. https://doi.org/10.1007/s00421-010-1666-5

21. Scott C. Quantifying the immediate recovery energy expenditure of resistance training. J Strength Cond Rec. 2011; 25(4): 1159-1163. https://doi.org/10.1519/JSC.0b013e3181d64eb5

22. Stec M, Rawson E. Estimation of resistance exercise energy expenditure using triaxal acceleromtry. J Strenght Cond Res. 2012; 26(5): 1413-1422. https://doi.org/10.1519/JSC.0b013e318248d7b4

23. Wilmore JH, Parr RB, Ward P, Vodak PA, Barstow TJ, Pipes TJ, et al. Energy cost of circuit weight training. Med Sci Sports Exerc. 1978; 10: 75-78.

24. Ainsworth B, Haskell W, Herrmann S, Bassett D, Tudor-Locke C, Greer J, et al. Compendium of physical activities: a second update of codes and MET values. Med Sci Sports Exerc. 2011; 43(8): 1575-1581. https://doi.org/10.1249/MSS.0b013e31821ece12

25. Westcott W. ACSM strength training guidelines: role in body composition and health enhancement. ACSM's Health Fit J. 2009; 13(4): 14-22. https://doi.org/10.1249/FIT.0b013e3181aaf460

26. Van Roie E, Delecluse C, Coudyzer W, Boonen S, Bautmans I. Strength training at high versus low external resistance in older adults: effects on muscle volume, muscle strength, and force-velocity characteristics. Exp Gerontol. 2013; 48(11): 1351-1361. https://doi.org/10.1016/j.exger.2013.08.010

27. Maté-Muñoz JL, Monroy AJA, Jiménez PJ, Garnacho-Castaño MV. Effects of instability versus traditional resistance training on strength, power and velocity in untrained men. J Sports Sci Med. 2014; 13(3): $460-468$.

28. Brzycki M. A practical approach to strength training. Chicago, IL: Masters Press; 1995.

29. American College of Sport Medicine. ACSM's health/fitness facility standards and guidelines. Fourth edition. Champaign: American College of Sport Medicine; 2012.

30. Poehlman ET, Denino WF, Beckett T, Kinaman KA, Dionne IJ, Dvorak R, et al. Effects of endurance and resistance training on total daily energy expenditure in young women: a controlled randomized trial. J Clin Endocrinol Metab. 2002; 87: 1004-1009. https://doi.org/10.1210/jcem.87.3.8282

31. Mazzetti S, Douglass M, Yocum A, Harber M. Effect of explosive versus slow contractions and exercise intensity on energy expenditure. Med Sci Sports Exerc. 2007; 39(8): 1291-1301. https://doi.org/10.1249/mss.0b013e318058a603

32. Philips WT, Ziuaritis JR. Energy cost of the ACSM single-set resistance training protocol. J Strength Cond Res. 2003; 17(2): 350-355. https://doi.org/10.1519/00124278-200305000-00023, https://doi.org/10.1519/1533-4287(2003)017<0350:ECOTAS>2.0.CO;2

33. Reilly T. The energy cost and mechanical efficiency of circuit weight-training. J. Hum. Movement Stud. 1983; 9: 39-45.

34. Glass SC, Reeg EA, Bierma JL. Caloric cost of martial arts training in novice participants. J Exerc Physiol. 2002; 5(4): 29-34.

35. Tucker JM, Welk GJ, Beyler NK. Physical activity in U.S. adults. Compliance with the Physical Activity Guidelines for Americans. Am Journal Prev Med. 2011; 40: 454-61. https://doi.org/10.1016/j.amepre.2010.12.016

36. Chastin SFM, Dall PM, Tigbe WW, Grant MP, Ryan CG, Rafferty D, et al. Compliance with physical activity guidelines in a group of UK-based postal workers using an objective monitoring technique. Eur J Appl Physiol. 2009; 106: 893-899. https://doi.org/10.1007/s00421-009-1090-x 
37. Colley R, Garriguet D, Janssen I, Craig CL, Clarke J, Tremblay MS. Physical activity of Canadian children and youth: accelerometer results from the 2007 to 2009 Canadian Health Measures Survey. PHR. 2011; 22(1): 7-14.

38. Scheers T, Philippaerts R, Lefevre J. Compliance with different physical activity recommendations and its association with socio-demographic characteristics using an objective measure. BMC Public Health. 2013; 13: 136-145. https://doi.org/10.1186/1471-2458-13-136

39. Mutikainen S, Helander E, Pietilä J, Korhonen I, Kujala UM. Objectively measured physical activity in Finnish employees: a cross-sectional studies. BMJ Open. 2014; 4(12): e005927. https://doi.org/10.1136/bmjopen-2014-005927

40. Dębska M, Mynarski W, Rozpara M, Puciato D. Habitual physical activity in adults measured by accelerometer in compliance with selected health recommendations. CEJSSM. 2007; 18(2): 99-105. 